NASA Technical Memorandum 87278

\title{
Performance and Endurance Tests of a Multipropellant Resistojet for Space Station Auxiliary Propulsion
}

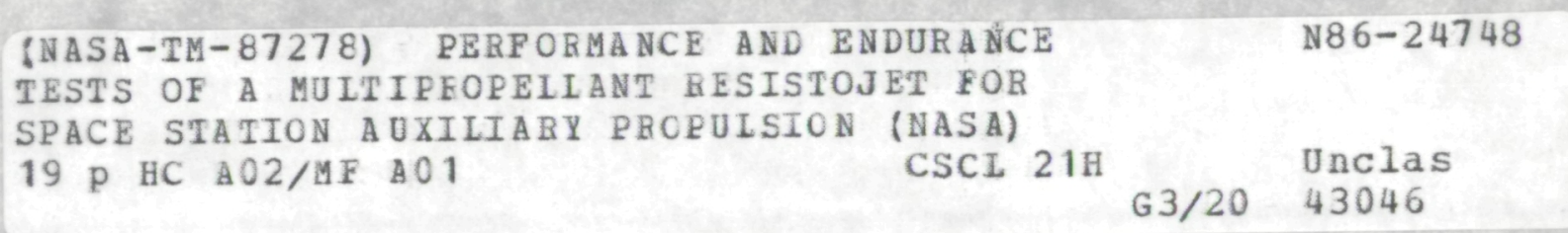

W. Earl Morren, Margaret V. Whalen, and James S. Sovey

Lewis Research Center

Cleveland, Ohio

Prepared for the

22nd Joint Propulsion Conference

cosponsored by the AIAA, ASME, SAE, and ASEE

Huntsville, Alabama, June 16-18, 1986

\section{N/SA}

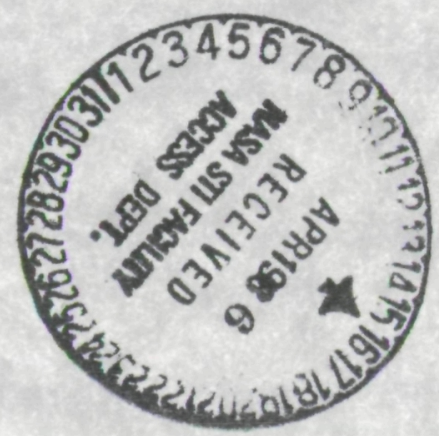


W. Earl Morren, Margaret V. Whalen, and James S. Sovey National Aeronautics and Space Administration

Lewis Research Center

Cleveland, Ohio 44135

\section{Abstract}

This paper presents the results of an effort by the NASA Lewis Research Center (LeRC) to demonstrate the technology readiness of a long-life multipropellant resistojet for Space Station auxiliary propulsion. Experiments were performed to evaluate the compatibility of grain-stabilized platinum tubes at temperatures up to $1400{ }^{\circ} \mathrm{C}$ in environments of $\mathrm{CO}_{2}, \mathrm{CH}_{4}, \mathrm{NH}_{3}, \mathrm{H}_{2} \mathrm{O}$, and $\mathrm{H}_{2}$. All samples tested showed extrapolated lifetimes in excess of $10,000 \mathrm{hr}$ based on 10 percent mass loss as end-of-life. However, samples tested in an ammonia atmosphere at $1400^{\circ} \mathrm{C}$ showed severe pitting, which raised concerns about the compatibility of grain-stabilized platinum with ammonia-containing atmospheres. Additional tests showed that reducing the metal temperature to about $900{ }^{\circ} \mathrm{C}\left( \pm 100{ }^{\circ} \mathrm{C}\right)$ significantly reduced this adverse effect. Characterizations of a simple, radiatively-coupled design fabricated from grain-stabilized platinum on a variety of fluids were performed. Propellant gases used included hydrogen, helium, methane, air, nitrogen, argon, and carbon dioxide. Thrust levels observed ranged from $90 \mathrm{mN}$ to $420 \mathrm{mN}$ at input electric power levels from 140 to $240 \mathrm{~W}$. Measured specific impulse values ranged from 100 to $400 \mathrm{sec}$. Endurance testing of the same type of thruster using $\mathrm{CO}_{2}$ propellant was begun, and at the time of this writing 1400 operating cycles with on-time of about $1160 \mathrm{hr}$ have been achieved.

\section{Introduction}

During the 1960's there was an active technology effort to develop resistojets for the Manned Orbital Research Laboratory (MORL) using Environmental Control and Life Support Systems (ECLSS) effluents. The MORL program, and the associated biowaste resistojet technology work, ${ }^{1-4}$ was terminated in the early 1970's. Over the past six years, high-performance hydrazine resistojets have performed North-South stationkeeping for Intelsat and RCA spacecraft in geosynchronous orbit, marking a renewed interest in resistojet technology. Two thruster developers have provided approximately one hundred resistojet thrusters for twenty-six

f 7 ights. 5,6 Resistojets have also been considered for auxiliary propulsion of spacecraft operating at low earth orbit. Recently, a resistojet technology program was reinstated by NASA to focus on materials evaluation, fabrication methods, performance, and life assessments for Space Station application. The technology development goals are to emphasize thruster life and multipropellant capability rather than performance.

The Lewis Research Center (LeRC) is actively involved in propulsion component technology in support of Space Station Advanced Development Program. The resistojet is one of the propulsion options being investigated ${ }^{8}$ due to its unique ability to provide thrust for atmospheric drag make-up while disposing of a wide variety of excess fluids expected to be present on board Space Station. The resistojet can vent these excess gases propulsively or nonpropulsively, insuring no change of phase occurs during venting. Significant Space Transportation System (STS) costs would be associated with the disposal of unwanted fluids from Space Station. These costs would be reduced substantially with the use of resistojets for waste fluid disposal. Recent studies have explored these and other potential benefits of propulsion systemis which use low-thrust resistojets. $9-10$

In an effort to reduce Space Station servicing costs associated with thruster replacement, emphasis has been placed on thrusters designed for long life rather than high performance. To this end, the selected thruster designs utilize a structurally rugged heater/heat exchanger assembly. The design life goal is $10000 \mathrm{hr}$ for thrusters operating on hydrogen, helium, methane, nitrogen, air, argon, and carbon dioxide at specific impulse values ranging from 100 to $500 \mathrm{sec}$. Sources and types of Space Station fluids suitable for use as resistojet propellants are itemized in Table I.

The objective of this program was to develop a laboratory model resistojet which would facilitate verification of performance predictions, thruster material/propellant compatibility, weld integrity, and provide preliminary lifetime data for operation in a thermally cyclic mode. A simple, rugged laboratory model resistojet was fabricated from grain-stabilized platinum. This thruster design was characterized on a variety of propellant gases at heater temperatures of $1400^{\circ} \mathrm{C}$. The same type of thruster has begun endurance testing using $\mathrm{CO}_{2}$ propellant. A more refined thruster with improved long life characteristics has been designed under contract with LeRC by the Rocketdyne, Division of Rockwell International and Technion. 11 These thrusters will be tested for performance and endurance at LeRC, and will also be sent to Marshall Space Flight Center for test-bed evaluation.

This paper will discuss briefly the rationale for the material chosen for the multipropellant resistojet. The results of performance evaluations of the laboratory model resistojet operating on hydrogren, helium, methane, air, nitrogen, argon, and carbon dioxide will then be presented. Finally, the progress of an ongoing endurance test of the laboratory model resistojet using $\mathrm{CO}_{2}$ propellant will be reviewed.

\section{Apparatus and Procedure}

\section{Thruster Design Description}

A radiatively-coupled heat exchanger was chosen for the laboratory model thruster to separate the heating element from the propellant, thus minimizing the effects of any potential propeliant/heater material interaction. The heating element is made from a $2.03 \mathrm{~mm} \mathrm{o.d}$. by $1.52 \mathrm{~mm} \mathrm{i.d.} \mathrm{coiled} \mathrm{tube} \mathrm{and}$ 
is placed inside a concentric tube heat exchanger (Fig. 1). The tubular heater is comprised of 22 turns over a length of $5.82 \mathrm{~cm}$. To reduce heat losses from the rear of the thruster, the propellant flow path was lengthened near the propellant inlet by channeling the flow circumferentially around the heat exchanger body. The flow is then directed axially toward the nozzle after passing through 16 small channels contained within the forward (hottest) portion of the heat exchanger. The hot gases then exit through the nozzle.

The multipropellant thruster assemblies tested were fabricated entirely from zirconia grain-

stabilized platinum. The coiled tube heaters were also made from grain-stabilized platinum. Components were joined using electron beam welding. Design characteristics of the thrusters are summarized in Table II.

The thrusters were wrapped with radiation shielding consisting of two layers of $0.025 \mathrm{~mm}$ platinum foil followed by 13 layers of $0.127 \mathrm{~mm}$ stainless steel foil. The layers of shielding were separated by small diameter wires.

\section{Measurement Apparatus}

The resistojets were characterized using a thrust stand derived from a TRW-designed device which uses the horizontal displacement of a mounting plate as an indication of applied thrust. ${ }^{6}$ Figure 2 illustrates this thrust stand schematically. The mounting plate is made from a machinable ceramic material to reduce heat transier from the thruster mounts to the rest of the thrust stand, and is supported on four flexures made from stainless steel shim stock. Displacement of the mounting plate is monitored using a linear variable differential transformer (LVDT). The output of the LVDT was calibrated against thrust using small weights (approximately $148 \mathrm{mN}$ each) hung from a length of cord. A low-friction pulley transfers the vertical force exerted on the cord by gravity into a horizontal (thrust) force. The magnitude of the calibration thrust was changed by varying the number of calibration weights supported by the cord. This was accomplished using a movable weight pan.

Electrical power was supplied to the thruster by two $0.32 \mathrm{~cm}$ diameter copper rods. Propellant was fed to the thruster through a length of $0.32 \mathrm{~cm} \mathrm{o.d.}$ thin-walled stainless steel tubing. A second tube (identical to the propellant feed line) connected the thruster inlet to a pressure gauge. The propellant feed tube and the pressure tap tube were shaped in a sine-wave configuration to minimize their lateral stiffnesses, thus increasing the sensitivity of the thrust stand.

The thruster mounting plate and LVDT were submerged in an oil bath to minimize thermal expansion of the plate and the associated thermal drift in the LVDT output. This thrust system yielded a standard deviation in indicated thrust of approximately $1 \mathrm{mN}$ during calibration. Thermal drift during operation at the power levels required was minimal. This drift was negated by allowing the thruster to establish equilibrium at each operating point, then turning off the propellant flow to cancel thrust, allowing a new thrust stand zero reading to be established. The thruster was assumed to be at equilibrium when the inlet pressure, heater voltage, and heater current readings stabilized. Figure 3 shows a photograph of the multipropellant resistojet mounted on the thrust stand, ready for performance testing.

\section{Power Processing}

Heater power was supplied by a dc power supply with an output capacity of $50 \mathrm{~V}$ at $50 \mathrm{~A}$. This unit is operable in both voltage-and currentlimiting modes. The dc power supply was used in conjunction with a dc resistance controller designed at LeRC which allowed constant heater resistance operation of the thruster. Heater power consumption was calculated from measurements of current and voltage at the thruster heater terminals.

\section{Propellant Flow Measurement}

Propellant flow rates were measured using transducers which are thermally sensitive to gas mass flow rate and heat capacity. These flow transducers were calibrated for output reading versus actual mass flow rate for each of the propellants used in the multipropellant resistojet. The calibration curves obtained were linear over the flow rate ranges tested. The uncertainty in the measured values of the propellant gases is estimated to be better than 3 percent for all but the lowest flow rates measured.

\section{Test Chamber}

The characterizations of the multipropellant resistojets were conducted in a vacuum chamber measuring $4.6 \mathrm{~m}$ in diameter and $19 \mathrm{~m} 1 \mathrm{ong}, 12$ and utilizing a pumping train consisting of twenty $0.8 \mathrm{~m}$ diameter oil diffusion pumps backed by four positive displacement, lobe-type rotary blowers and four oil-sealed rotary piston vacuum pumps. With no flow into the tank this pumping train can achieve pressures of approximately $4 \times 10^{-7}$ torr. Tank pressures of less than $6 \times 10^{-4}$ torr are attainable even at hydrogen flows of 10 standard liters per minute. Data relating some flow rates and the corresponding tank pressures for hydrogen and nitrogen are summarized in Table III.

\section{Material Compatability Testing}

The requirement that the Space Station resistojet be capable of operation for extended periods of time on a variety of propellants is extremely stringent, since the range of fluids of interest includes both oxidizing and reducing gases. The material chosen for this application was grainstabilized platinum. This platinum-based material was believed to have an adequate combination of high-temperature strength and corrosion resistance in both oxidizing and reducing atmospheres. The grain stabilization is desired to minimize grain growth which occurs when materials are held at high temperatures for extended periods of time. Unfortunately, published information on the long-term compatibility of grain-stabilized platinum with the propellants of interest at $1400{ }^{\circ} \mathrm{C}$ was not available. Therefore, a study was conducted to evaluate the effects of long-term exposure of high-temperature grain-stabilized platinum tubes to environments of carbon dioxide, methane, hydrogen, ammonia, and steam.13-14 
Two facilities were used in the grain-stabilized platinum compatibility tests. Figure 4 shows the test chamber used in the tests with the flowing $\mathrm{H}_{2}, \mathrm{CH}_{4}$, and the $\mathrm{CO}_{2} / \mathrm{CH}_{4}$ mixtures. A schematic of the apparatus is shown in Figure 5 . The $2.54 \mathrm{~cm} \mathrm{o.d}$. by $20.3 \mathrm{~cm}$ chamber was constructed of a quartz tube with metalized ends. The test chamber was mounted in the bell jar of a vacuum tank. A mechanical roughing pump was used in purging the chamber and maintaining the cell pressure. A current-controlled dc power supply with a $100 \mathrm{~A}, 100 \mathrm{~V}$ maximum capacity was used in each experiment. The test piece was coiled from $0.203 \mathrm{~cm}$ o.d. by $0.025 \mathrm{~cm}$ wall tubing. It was supported by $0.635 \mathrm{~cm}$ diameter power leads. The platinum-yttria experiment in ammonia incorporated a similar test cell, except the chamber was stainless steel with a quartz viewing window.

An additional experimental facility employed a $45.7 \mathrm{~cm}$ diameter stainless steel bell jar. This bell jar was used for platinum-yttria coil tested in stagnant $\mathrm{CO}_{2}$. A roughing pump was used in initial purging and in test shutdown procedures. The same type of power supply and similar specimen mounting arrangement were used in each experiment.

The grain-stabilized platinum tubes were first vacuun annealed at $1000^{\circ} \mathrm{C}$ for $30 \mathrm{~min}$. This anneaiing made the tube specimens ductile enough to be coiled. Each coiled tube was cleaned with NA-500 (a degreaser), then rinsed with ethyl alcohol and dried with high-purity nitrogen gas. The mass of each coil was then measured using an analytical balance readable to $0.1 \mathrm{mg}$.

A series of experiments to determine the compatibility of a grain-stabilized platinum with $\mathrm{H}_{2}$, $\mathrm{CH}_{4}, \mathrm{NH}_{3}, \mathrm{CO}_{2}, \mathrm{CH}_{4}$, and $\mathrm{H}_{2} \mathrm{O}$ was performed. Each colled tube was maintained at high temperature ( 500 to $1400{ }^{\circ} \mathrm{C}$ ) in a flowing gas environment at ambient pressures of about $1.4 \mathrm{~atm}$. Gas flow rates through the test cells were approximately 100 standard $\mathrm{cm}^{3} / \mathrm{min}$. Samples tested in $\mathrm{H}_{2}, \mathrm{CO}_{2}, \mathrm{NH}_{3}$, and $\mathrm{H}_{2} \mathrm{O}$ were heated to $1400{ }^{\circ} \mathrm{C}$, while samples tested in $\mathrm{CH}_{4}$-containing environments were heated to about $500{ }^{\circ} \mathrm{C}$ to avoid $\mathrm{CH}_{4}$ dissociation. Another test was performed in a stagnent $\mathrm{CO}_{2}$ environment at a coil temperature of about $1300^{\circ} \mathrm{C}$. Test cell pressure for this test was about $0.7 \mathrm{~atm}$.

\section{Performance Test Procedure}

Performance of the thrusters was measured for each of the seven propellants over a range of thrust levels at constant heater temperature. The constant heater temperature performance was obtained using a dc resistance controller. Heater temperature for all tests was $1400^{\circ} \mathrm{C}$, and was determined based on a temperature-resistance calibration obtained using a two-color optical pyrometer.

\section{Endurance Testing}

One of the two laboratory model resistojets made from grain-stabilized platinum was installed in a small vacuum chamber (Fig. 6) for endurance testing using $\mathrm{CO}_{2}$ propellant. The propellant mass flow was held constant at approximately $0.125 \mathrm{~g} / \mathrm{s}$, while the heater power was cycled at a frequency of one cycle per hour with a duty cycle of 83 percent.
The heater temperature at steady state was approximately $1400^{\circ} \mathrm{C}$. This type of operation causes periodic fluctuations in both thermal and mechanical stresses.

Operating parameters monitored included heater voltage and current, propellant mass flow rate, feed system and thruster inlet pressures, test chamber pressure, and outside radiation shield layer temperature. Thrust was not monitored in an effort to reduce test apparatus complexity.

\section{RESULTS AND DISCUSSION}

\section{Material Compatability Results}

The results of the material compatibility experiments, summarized in Table IV, indicate that grain-stabilized platinum tubes are compatible with carbon dioxide, methane, hydrogen, and steam under the test conditions. The extrapolated lifetimes, based on ten percent mass loss as end of life, are well in excess of the design life goal of $10000 \mathrm{hr}$ in all cases. Figure 7 shows two cross sections of one of the grain-stabilized platinum test specimens: the first was taken before testing; the second was taken after $2000 \mathrm{hr}$ of exposure to $\mathrm{CO}_{2}$ at a coil temperature of $1300^{\circ} \mathrm{C}$. It is apparent that no significant grain growth has occurred, and that attack of the sample surfaces by the environment are minimal. These photos are typical of the results observed for specimens tested in $\mathrm{CO}_{2}, \mathrm{H}_{2}, \mathrm{CH}_{4}$, and steam.12-13 The sample tested in ammonia, however, showed pitting that extended well into the material, which could affect the material strength and indicate a potential interaction between grainstabilized platinum and hydrazine decomposition gas products. Reducing the operating temperature of the platinum surfaces to about $900{ }^{\circ} \mathrm{C}$ when exposed to ammonia-containing atmospheres resulted in a significant reduction in such pitting.

Based on this investigation, grain-stabilized platinum should be suitable for use over extended periods of time at high temperatures for the fluids tested, although it may be necessary to limit the material temperature in ammonia environments to less than $1000^{\circ} \mathrm{C}$.

\section{Characterization Test Results}

Thruster evaluation was undertaken at a power level of about $200 \mathrm{~W}$ for thrust levels ranging from 90 to $420 \mathrm{mN}$. Specific impulse, thrust, and input power parameters are reported for each of the seven propellants. The data were also reduced to examine the values of overall efficiencies.

With this simple, radiatively-coupled thruster design, large temperature drops between the thruster heater and heat exchanger were expected. Estimates of the temperature difference between the heater and heat exchanger range from $360{ }^{\circ} \mathrm{C}$ for low-thrust operation on argon propellant to $1290{ }^{\circ} \mathrm{C}$ for operation on hydrogen at high thrust levels. These estimates were based on the assumption that the wall temperature was approximately equal to the estimated final gas temperature. The gas temperatures were calculated by performing an energy balance on the gas as it passed through the heat exchanger. The power in the gas leaving the heat exchanger, 

Pgf, is the thrust power divided by the square of
the' nozzle efficiency:

$$
P_{g f}=\frac{T \star I_{s p}{ }^{\star} g}{2 n_{\text {nozzle }}^{2}}
$$

Where $T$ and $I_{S p}$ are the measured values of thrust and specific impulse, respectively, and nnozzle is the nozzle efficiency, defined as the ratio of the actual specific impulse to that predicted by one-dimensional isentropic flow equations for a nozzle with the same area ratio as the one being investigated.

The power in the gas entering the heat exchanger, $\mathrm{P}_{\text {go }}$, is:

$$
\mathrm{P}_{\text {go }}=\dot{\mathrm{mh}}_{\mathrm{O}}
$$

Where $\dot{m}$ is the mass flow rate and $h_{0}$ is the cold $(300 \mathrm{~K})$ gas enthalpy. The power added to the gas within the heat exchanger is the difference between $\mathrm{Pgf}_{\mathrm{gf}}$ and $\mathrm{P}$ go, and can be equated to the product of the mass flow rate and the enthalpy rise of the gas:

$$
\dot{m}\left(h_{f}-h_{0}\right)=\frac{T^{\star} I s{ }^{\star} g_{e}}{2 n_{\text {nozzle }}^{2}}-\dot{m} h_{0}
$$

from which the enthalpy of the gas leaving the heat exchanger, $h_{f}$, can be calculated. This value was then used with standard gas property tables 15 to determine the final gas temperature. The value of the nozzle efficiency was assumed to be 0.95 based on estimates used previously by Zafran and Jackson.

Figure 8 shows the ranges of thrust levels and specific impulse values observed for the multipropellant resistojet for the various propellants at heater temperatures of approximately $1400{ }^{\circ} \mathrm{C}$. This heater temperature was chosen due to heater material temperature limitations. Because of the configuration of the heater element, this temperature limitation caused maximum power dissipation from the heater to be in the vicinity of $200 \mathrm{~W}$. Flow rates for all propellants ranged from 0.08 to $1.6 \mathrm{~kg} / \mathrm{hr}$ at stagnation temperatures from approximately $110{ }^{\circ} \mathrm{C}$ for hydrogen at high flow rates to about $1040{ }^{\circ} \mathrm{C}$ for argon at low flow rates.

Figures 9 through 11 illustrate the variations of specific impulse and input electric power with thrust for the seven propellants tested at heater temperatures of approximately $1400{ }^{\circ} \mathrm{C}$. Thrust levels were varied by changing the propellant mass flow rate. Power consumption varied approximately as the square root of thrust.

The maximum specific impulse values obtained ranged from a high of $402 \mathrm{sec}$ for hydrogen to a low of $133 \mathrm{sec}$ for argon. The high values of specific impulse measured for the remaining five gases were $278,180,154,148$, and $122 \mathrm{sec}$ for helium, methane, nitrogen, air, and carbon dioxide, respectively. Specific impulse values at $300 \mathrm{~K}$ are also shown in Figures 9 through 11 .

Figure 12 shows the ranges of overall efficiencies calculated for the multipropellant resistojet for heater temperatures of $1400{ }^{\circ} \mathrm{C}$ for the seven propellant fluids. The specific impulse values at which the maximum and minimum efficiencies were calculated are also given. The maximum efficiencies generally correspond to the minimum specific impulse values. Similar resistojet characterizations performed at higher heater temperatures using hydrogen, ammonia, and pitrogen propellants were recently reported by TRW 16 and Rocket Research. 1

\section{Endurance Test Progress}

The laboratory model resistojet made from grain-stabilized platinum is currently undergoing endurance testing on carbon dioxide propellant. Thruster inlet pressure varies from 0.12 to 0.19 $\mathrm{MPa}$, corresponding to thrust levels on the order of 93 to $147 \mathrm{mN}$. The maximum temperature on the outer layer of the radiation shield reaches about $300{ }^{\circ} \mathrm{C}$ at eguilibrium under power, and drops to about $170 \mathrm{C}$ during the cool down period of each cycle.

Difficulties encountered thus far have been confined to the heater element. The heater design, originally conceived for use in a rhenium thruster, does not provide sufficient rigidity at high temperature to withstand gravitational stresses. This resulted in a tendency for the heater to sag, contacting the inside of the thruster body and causing a short circuit. This problem was remedied by installing a heater support structure (see Fig. 1) made of ion sputtered or vapor-deposited platinum on alumina. While interactions between platinum and alumina at high temperatures have been observed in the past 18 to cause degradation of the platinum structure, preliminary tests suggest that applying a thin coating (nominally $2000 \AA$ ) of platinum retards this interaction. This support structure allowed about 15-1/2 of the 22 turns of the heater coil to view the inside wall of the heat exchanger.

As of this writing this thruster has completed more than one-half of the planned 2000-hr (2400 thermal-cycles) endurance test using carbon dioxide propellant. As shown in Figure 13, the heater voltage has dropped from an initial value of $6.7 \mathrm{~V}$ to approximately $5 \mathrm{~V}$ with a variation of about $0.3 \mathrm{~V}$ on an intermittant basis. The reason for the variation is believed to be the occasional opening and closing of a contact point between two or more of the turns of the heater coil. Heater current is held constant at $29.0 \mathrm{~A}$ during the 83 percent of each 1 hour cycle that power is supplied to the heater. Thus the reduction in heater voltage has caused a drop on the electric power consumed by the heater from $194 \mathrm{~W}$ to approximately $145 \mathrm{~W}$. However, Figure 14 shows that the change in the estimated specific impulse over the course of the life test has varied by less than 10 percent. These estimates were made by comparing the ratio of the electric power to the mass flow rate for the life test thruster to a curve calibrating specific impulse to this ratio. The data used to generate this curve was obtained prior to the beginning of the life test.

The goals of this effort were to evaluate the compatibiliby of the grain-stabilized platinum thruster material with one of the fluids of interest for an extended period of time under conditions which one would expect to be encountered during normal use. 
In addition, information about the effects of cyclic thermal and mechanical stresses on the material itself as well as the welded joints could be gained.

In future efforts, an engineering model multipropellant resistojet supplied by the Rocketdyne Division of Rockwell International and Technion will be evaluated for performance and endurance in a manner similar to that described in this paper. This thruster design will eliminate the possibility of heater sag by using a sheathed heater element supported by a rugged heat exchanger body. 11

\section{Concluding Remarks}

Resistojet thrusters capable of operation for extended periods of time on a wide variety of fluids are candidates for Space Station auxiliary propulsion due to their unique ability to provide atmospheric drag make-up while disposing of excess fluids expected to be present onboard Space Station. Resistojets can vent unwanted fluids propulsively or non-propulsively, thereby reducing transportation costs associated with removing waste fluids from Space Station orbit.

Experiments were performed to evaluate the compatibility of grain-stabilized platinum tubes at temperature, up to $1400{ }^{\circ} \mathrm{C}$ in environments of $\mathrm{CO}_{2}$. $\mathrm{CH}_{4}, \mathrm{NH}_{3}, \mathrm{H}_{2} \mathrm{O}$, and $\mathrm{H}_{2}$. All samples tested showed" extrapolated lifetimes in excess of $10000 \mathrm{hr}$ based on 10 percent mass loss as end-of-life. However, samples tested in an ammonia atmosphere at $1400{ }^{\circ} \mathrm{C}$ showed severe pitting, which raised concerns about the compatibility of grain stabilized platinum with ammonia-containing atmospheres. Additional tests showed that reducing the metal temperature to about $900{ }^{\circ} \mathrm{C}\left( \pm 100^{\circ} \mathrm{C}\right)$ significantly reduced this adverse effect.

In an effort to demonstrate the technology readiness of the long-life multipropellant resistojet, laboratory model resistojets fabricated from grain-stabilized platinum were subjected to endurance testing using carbon dioxide and were characterized on hydrogen, helium, methane, air, nitrogen, argon, and carbon dioxide. Thrust levels observed during characterization ranged from $90 \mathrm{mN}$ to $420 \mathrm{mN}$ at input power levels ranging from $140 \mathrm{~W}$ to $240 \mathrm{~W}$. Specific impulse values calculated ranged from 96 to $402 \mathrm{sec}$. The endurance test has completed more than 1400 one hour cycles with a heater duty cycle of 83 percent.

\section{References}

1. Halbach, C.R., "10 mlb Biowaste Resistojet Performance," AIAA Paper 71-687, June 1971.

2. Murch, C.K. and Krieve, W.F., "Electrothermal Thruster Performance with Biowaste Propellants," AIAA Paper 70-1161, Sept. 1970.

3. Bliss, J.R., Greco, R.V., and Nelson, W.G., "Biowaste Resistojet System Definition for the NASA Space Station," AIAA Paper 70-1132, Sept. 1970
4. Greco, R.V., Bliss, J.R., Murch, C.K., Clark, K.E., and Kelly, A.J., "Resistojet and Plasmá Propulsion System Technology," AIAA Paper 72-1124, Nov. 1972.

5. McKevitt, F.X., "Design and Development Approach for the Augmented Catalytic Thruster (ACT), " AIAA Paper 83-1255, June 1983.

6. Dressler, G.A., et al, "Flight Qualification of the Augmented Electrothermal Hydrazine Thruster," AIAA Paper 81-1410, 1981.

7. Jones, R.E., "Space Station Propulsion: The Advanced Development Program at Lewis," NASA TM-86999, July 1985 .

8. Mirtich, M.J., "Resistojet Propuision for Large Spacecraft Systems," NASA TM-83489, 1982.

9. Donovan, R.M., Sovey, J.S., and Hannum, N.B., "Space Station Propulsion Analysis Study," AIAA Paper 84-1326, June 1984.

10. Garrison, D.W., and Klemetson, R.W., "Space Station Propulsion System Trade Study," AIAA Paper 83-1220, June 1983.

11. Pugmi re, T.K., Cann, G.L., Hechert, B., and Sovey, J.S., "A 10,000-Hour-Life Multipropellant Engine for Space Station Application," AIAA Paper 86-1403, June 1986.

12. Finke, R.C:, Holmes, A.D., and Keller, T.A., "Space Environment Facility for Electric Propulsion Systems Research," NASA TN D-2774, 1965.

13. Whalen, M.V., Grisnik, S.P., and Sovey, J.S., "Compatibility Experiments of Facilities, Materials, and Propellants for Electrothermal Thruster," NASA TM-86956, 1985.

14. Whalen, M.V., and Grisnik, S.P., "Compatibility of Grain-Stabilized Platinum with Candidate Propellants for Resistojets," AIAA Paper 85-2014, 1985.

15. McBride, B.J., et al, "Thermodynamic Properties to $6000^{\circ} \mathrm{K}$ for 210 Substances Involving the First 18 Elements," NASA SP-3001, 1963.

16. Zafran, S., and Jackson, B., "Electrothermal Thruster Diagnostics, "TRW Inc., Redondo Beach, CA, TRW-39152-6012-VE-00-Vol. 1; Vol. 2; May 1983. (NASA CR-168174)

17. Miyake, C.I., "Radiative Resistojet Performance Characterization Tests," Rocket Research Corp., Redmond, WA, Rept-84-R-958, Sept. 1984. (NÁSA CR-174763)

18. Darling, A.S., Selman, G.L., and Rushforth, R., "Platinum and the Refractory Oxides," Platinum Metals Review, Vol. 15., No. 1, Jan. 1971, pp. 13-18. 
TABLE I. - POTENIAL WASTE FLUID SOURCES FOR SPACE

STATION AUXILIARY PROPULSION

\begin{tabular}{|c|c|}
\hline \multicolumn{1}{|c|}{ Space Station Subsystem } & Waste Gases/Fluids \\
\hline ECLSS & \\
Bosch $\mathrm{CO}_{2}$ reduction & $\mathrm{H}_{2}, \mathrm{H}_{2} \mathrm{O}$ \\
Sabatier $\mathrm{CO}_{2}$ reduction & $\mathrm{CO}_{2}, \mathrm{CH}_{4}$ \\
Lab Modules & $\mathrm{Ar}, \mathrm{CO}_{2}, \mathrm{He}, \mathrm{H}_{2}$ \\
Material, life science & $\mathrm{N}_{2}, \mathrm{H}_{2} \mathrm{O}$ \\
Attached Payloads & $\mathrm{To} \mathrm{be} \mathrm{determined}_{\text {Miscellaneous purge gases }}$ \\
Orbit transfer vehicle tank farm & $\mathrm{N}_{2}, \mathrm{Ar}_{2}, \mathrm{GH}_{2}$ \\
\hline
\end{tabular}

TABLE II. - MULTIPROPELLANT RESISTOJET DESIGN CHARACTERISTICS

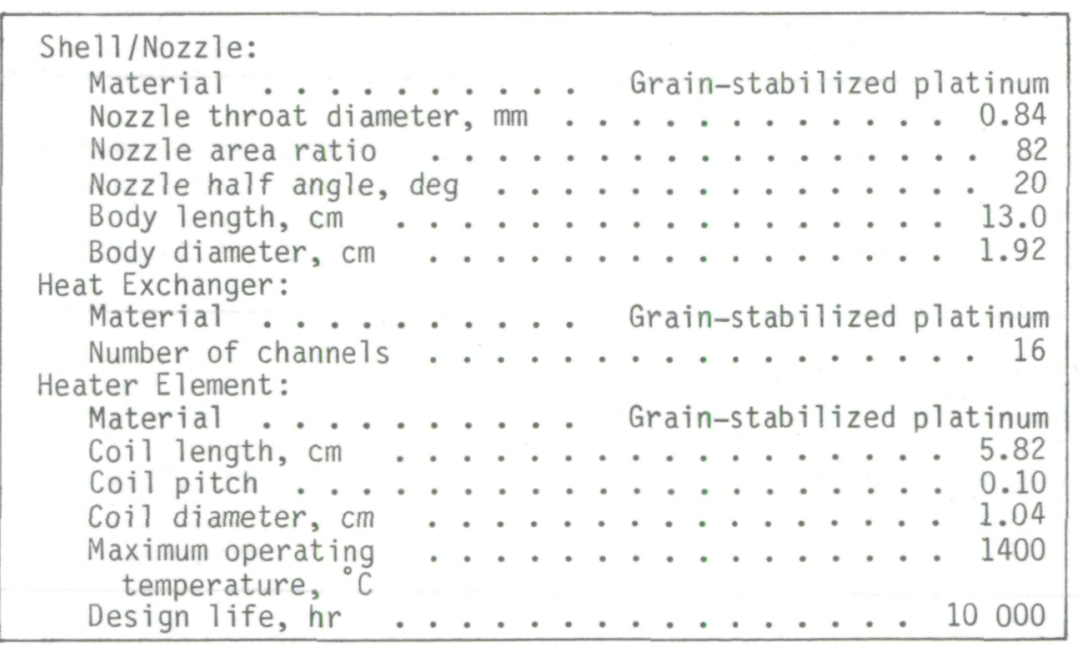


TABLE III. - VACUUM TANK 5 PUMPING CAPABILITY USING HYDROGEN AND NITROGEN WITH TWO PUMPING CONFIGURATIONS

\begin{tabular}{|l|c|c|c|c|}
\hline \multicolumn{1}{|c|}{$\begin{array}{c}\text { Pumping } \\
\text { configuration }\end{array}$} & \multicolumn{2}{|c|}{ Hydrogen } & \multicolumn{2}{c|}{ Nitrogen } \\
\cline { 2 - 5 } & $\begin{array}{c}\text { Flow rate } \\
\mathrm{g} / \mathrm{s}\end{array}$ & $\begin{array}{c}\text { Pressure } \\
\text { torr }\end{array}$ & $\begin{array}{c}\text { Flow rate } \\
\mathrm{g} / \mathrm{s}\end{array}$ & $\begin{array}{c}\text { Pressure } \\
\text { torr }\end{array}$ \\
\hline $\begin{array}{l}20 \mathrm{il} \\
\text { diffusion } \\
\text { pumps }\end{array}$ & 0.02 & $7 \times 10^{-4}$ & 0.1 & $5 \times 10^{-4}$ \\
\hline $\begin{array}{l}4 \text { Lobe blowers } \\
\text { and 4 oil } \\
\text { sealed rotary }\end{array}$ & 0.02 & $6 \times 10^{-2}$ & 0.1 & $4 \times 10^{-2}$ \\
\hline
\end{tabular}

apressure measured with cold cathode ionization gage with readings corrected for gas type.

TABLE IV. - SUMMARY OF GRAIN STABILIZED

PLATINUM EXPERIMENTS

\begin{tabular}{|c|c|c|c|c|}
\hline Propellant & $\begin{array}{c}\text { Coiled } \\
\text { heater } \\
\text { temp., } \\
\text { oc }\end{array}$ & $\begin{array}{c}\text { Heater } \\
\text { initial } \\
\text { mass, } \\
g\end{array}$ & $\begin{array}{c}\text { Coiled } \\
\text { heater } \\
\text { mass } \\
\text { loss, } \\
\mathrm{g}^{\mathrm{a}}\end{array}$ & $\begin{array}{c}\text { Extrapolated } \\
\text { life, } \\
\mathrm{hr}\end{array}$ \\
\hline
\end{tabular}

Platinum - Yttria

\begin{tabular}{|l|r|r|r|r|}
\hline $\mathrm{CO}_{2}$ & 1400 & 9.0194 & 0.0030 & 300000 \\
$\mathrm{CH}_{4}$ & 500 & 12.6384 & .0008 & 1500000 \\
$\mathrm{H}_{2}$ & 1400 & 12.6589 & .0062 & 200000 \\
$\mathrm{NH}_{3}$ & 1400 & 12.5982 & .0055 & 200000 \\
$\mathrm{H}_{2} \mathrm{O}$ & 1400 & 13.0695 & .0116 & 113000 \\
\hline
\end{tabular}

Platinum - Zirconia

\begin{tabular}{|l|r|l|l|r|}
\hline $\mathrm{CO}_{2}$ & 1400 & 13.1955 & 0.0016 & 800000 \\
$\mathrm{CH}_{4}$ & 500 & 11.6969 & $.0000^{\mathrm{C}}$ & 1000000 \\
$\mathrm{H}_{2}$ & 1400 & 13.2093 & .0031 & 400000 \\
$\mathrm{NH}_{3}$ & 1400 & 13.0632 & .0066 & 200000 \\
$\mathrm{H}_{2} \mathrm{O}$ & 1400 & 11.5133 & .0245 & 45000 \\
\hline
\end{tabular}

aAfter $1000 \mathrm{hr}$ operation.

b Time to 10 percent mass loss.

$\mathrm{c}_{0} .0001 \mathrm{~g}$, accuracy of balance. 

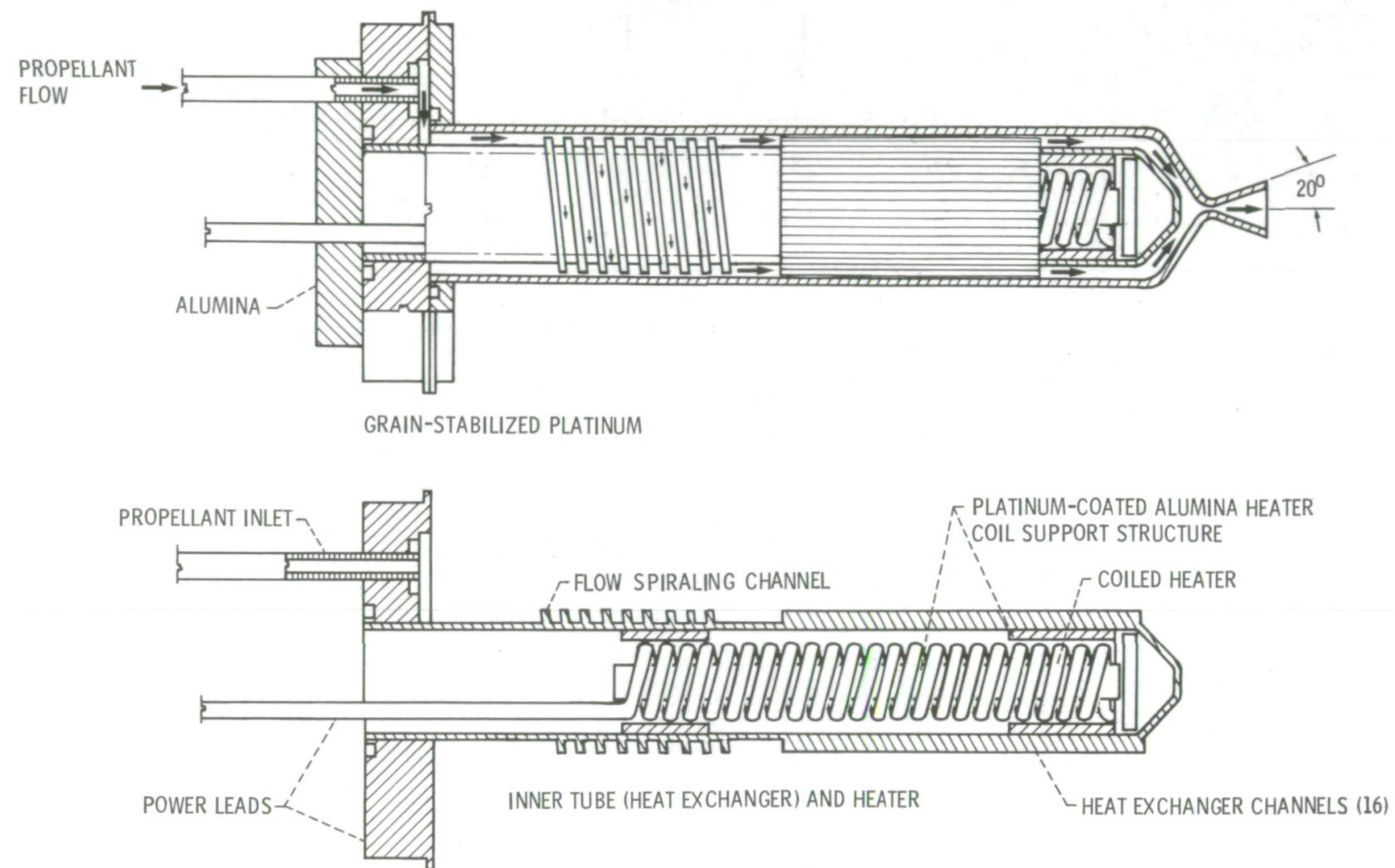

Figure 1. - Multipropellant resistojet cross-section.

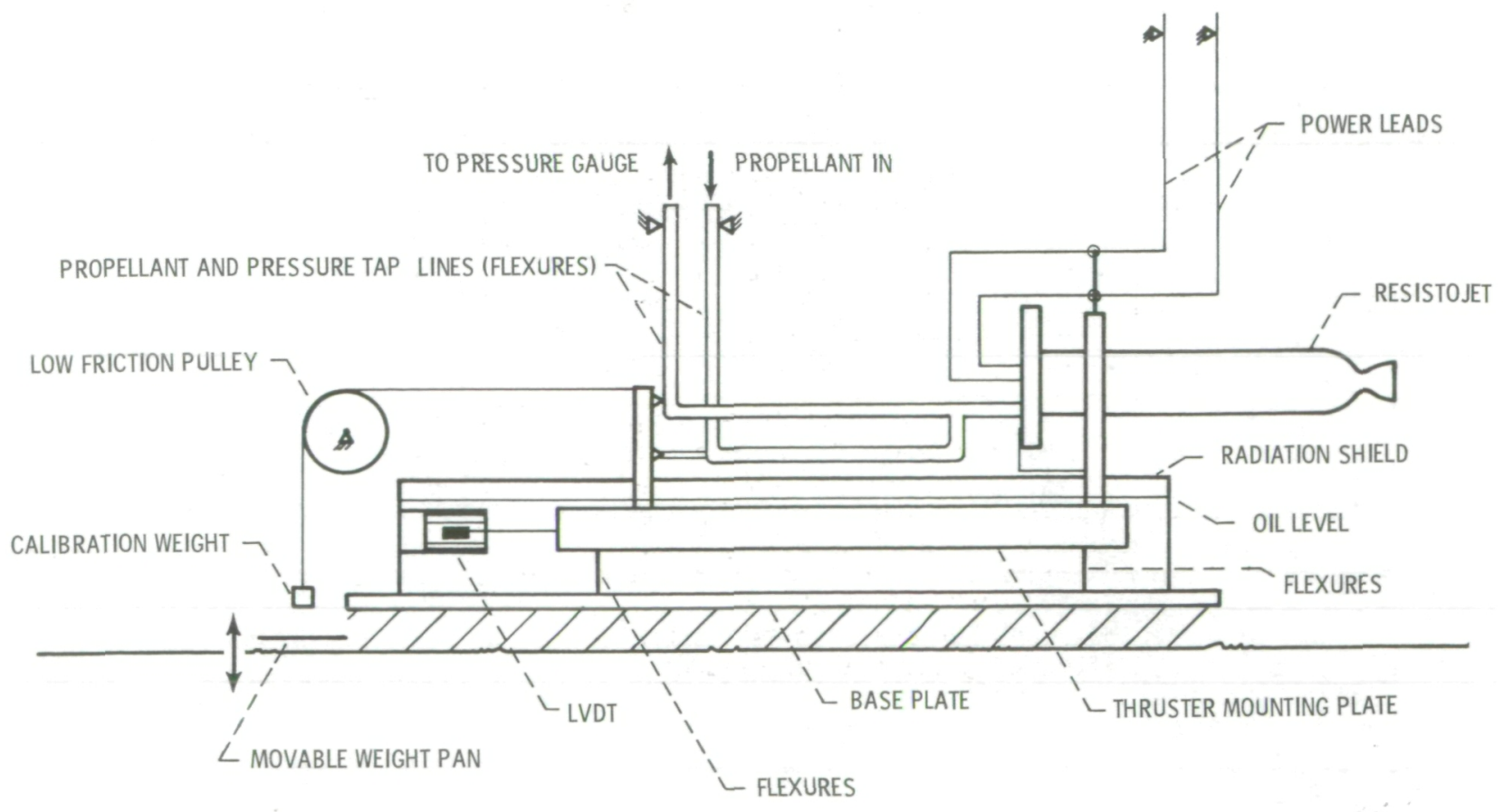

Figure 2. - Thrust stand schematic. 
ORIGINAL PAGE IS

OF POOR QUALITY

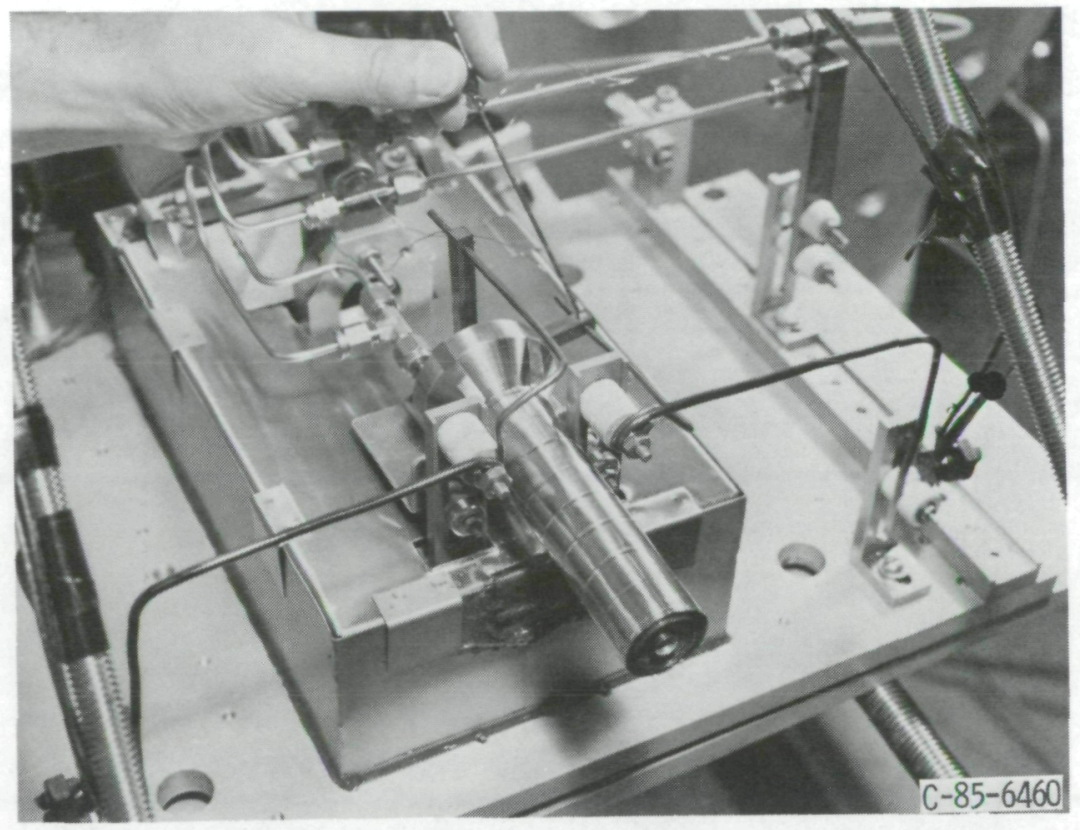

Figure 3. - Multipropellant resistojet mounted on thrust measurement system.

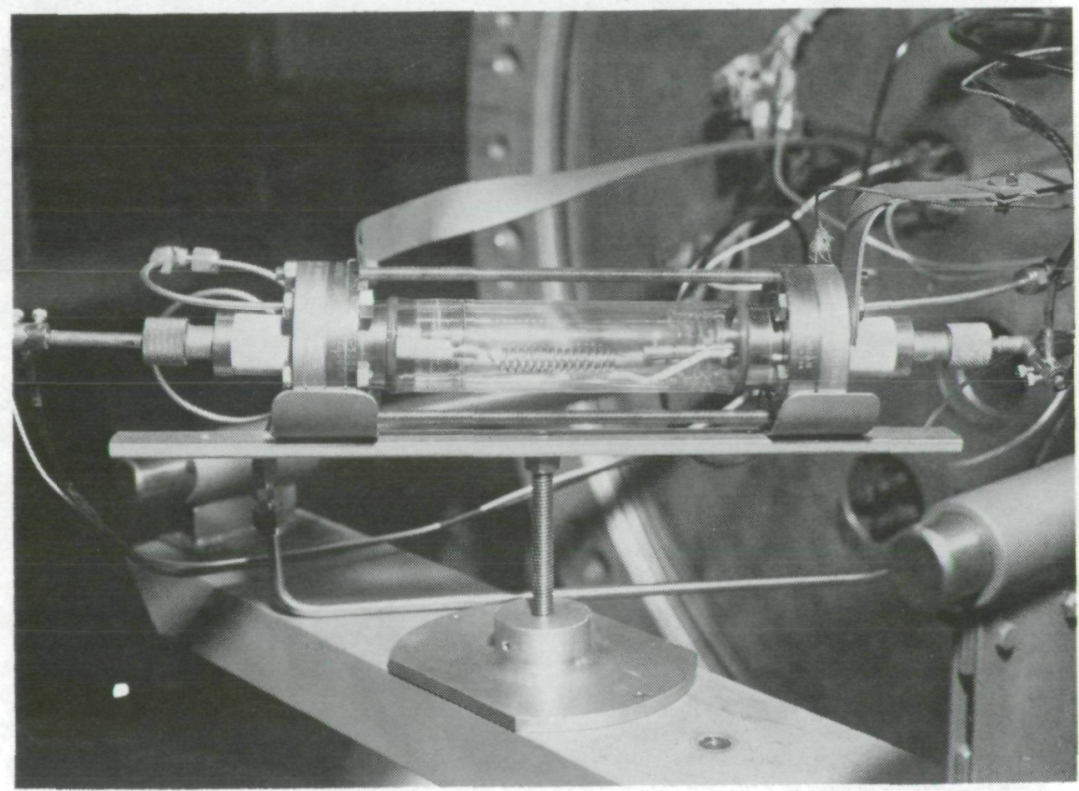

Figure 4. - Material test cell. 


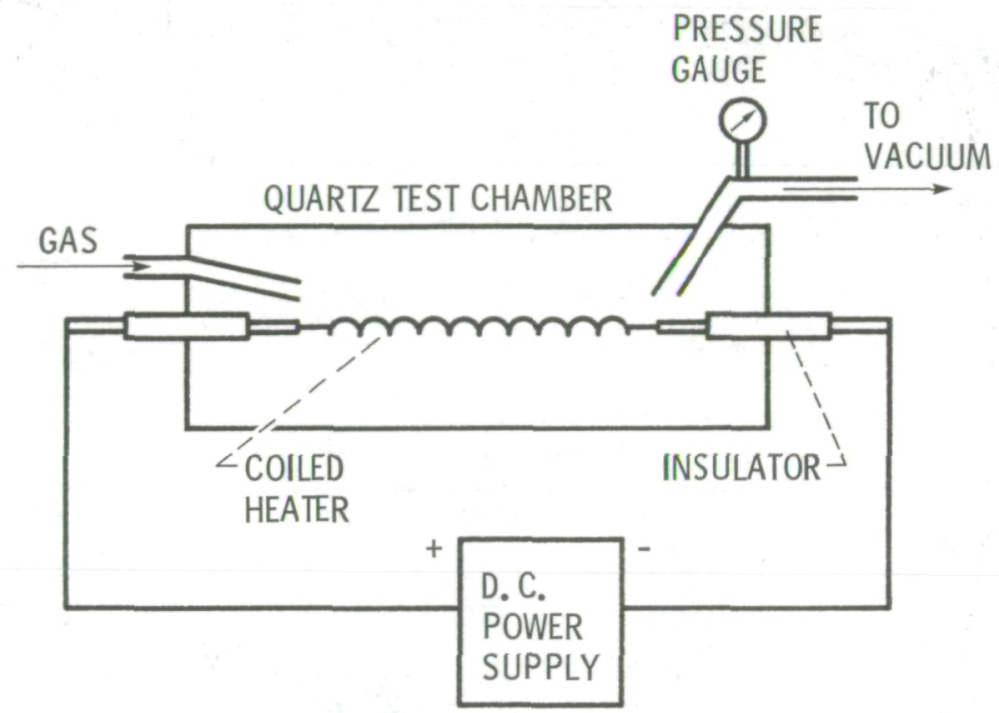

Figure 5. - Material experimental system.

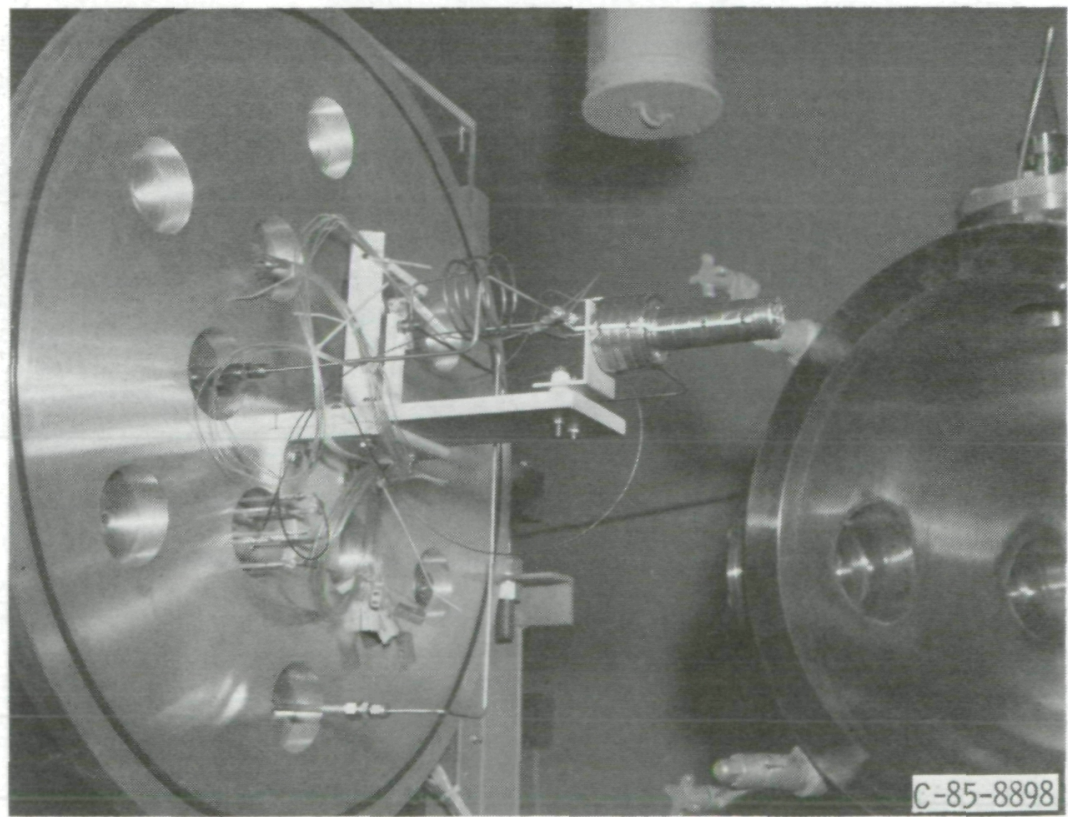

Figure 6. - Multipropellant resistojet installed in life test facility. 


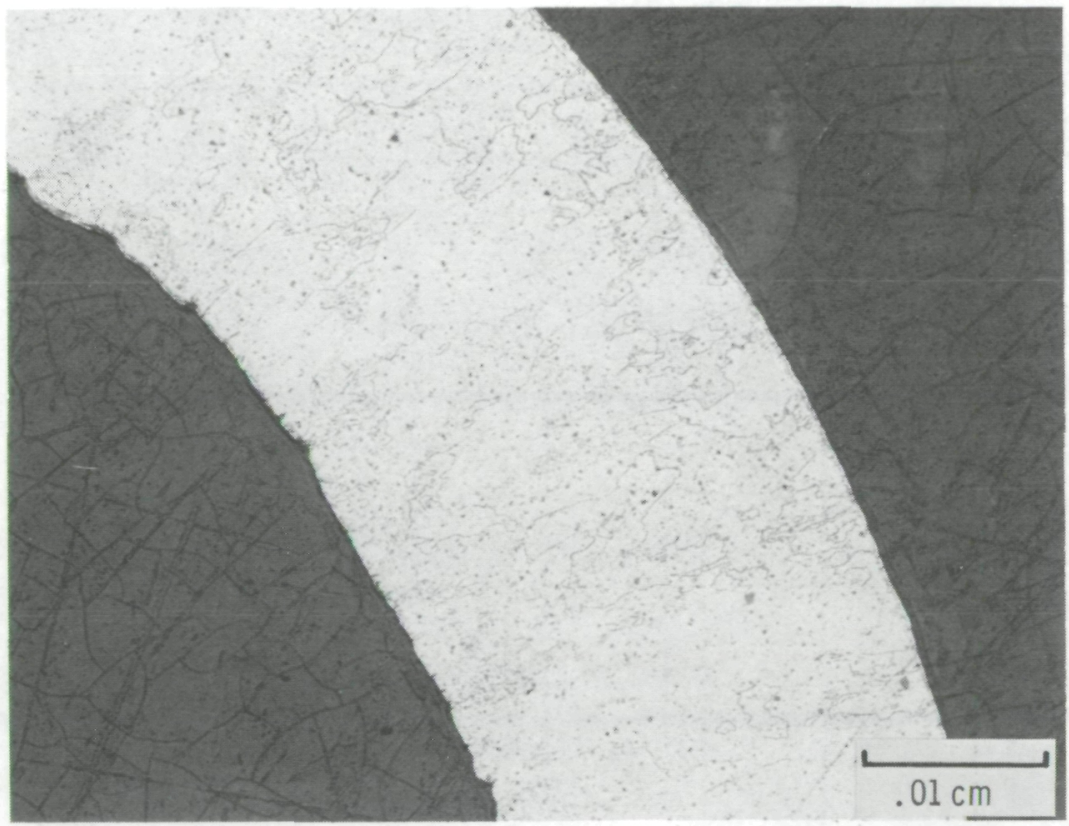

Before

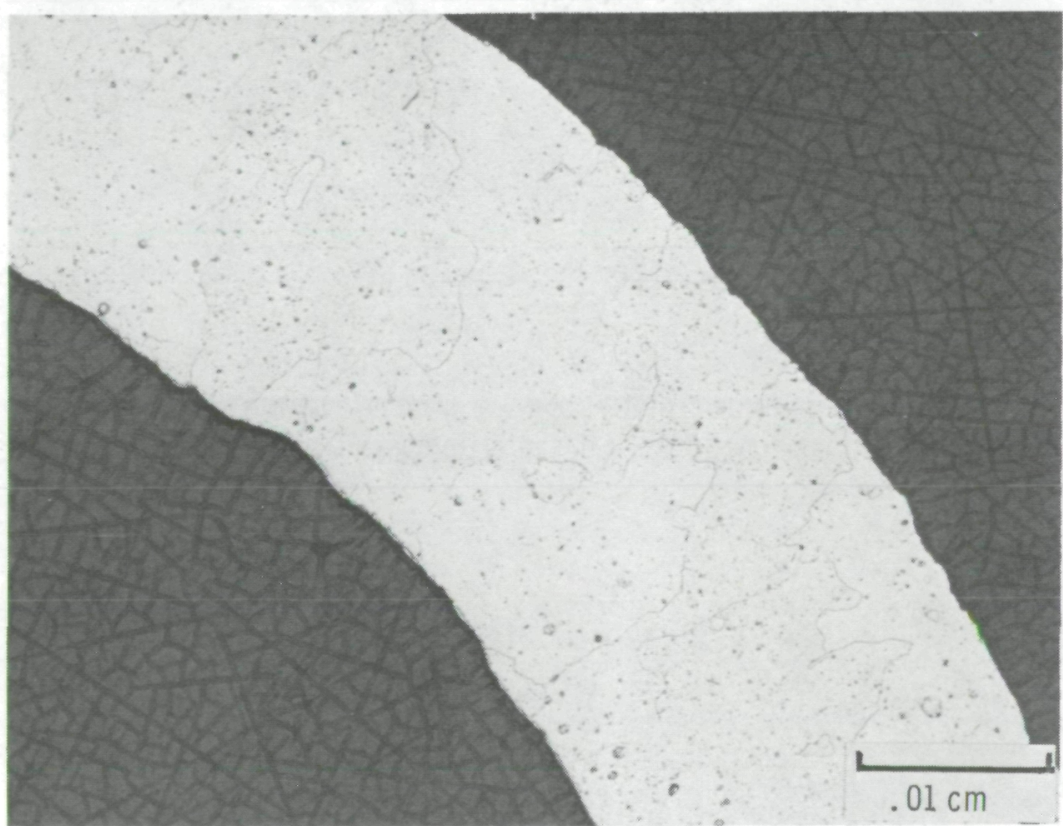

After

Figure 7. - Cross section of $\mathrm{Pt} / \mathrm{Y}_{2} \mathrm{O}_{3}$ tube before and after testing for $2000 \mathrm{hr}$ at $1300{ }^{\circ} \mathrm{C}$ in $\mathrm{CO}_{2}$. 


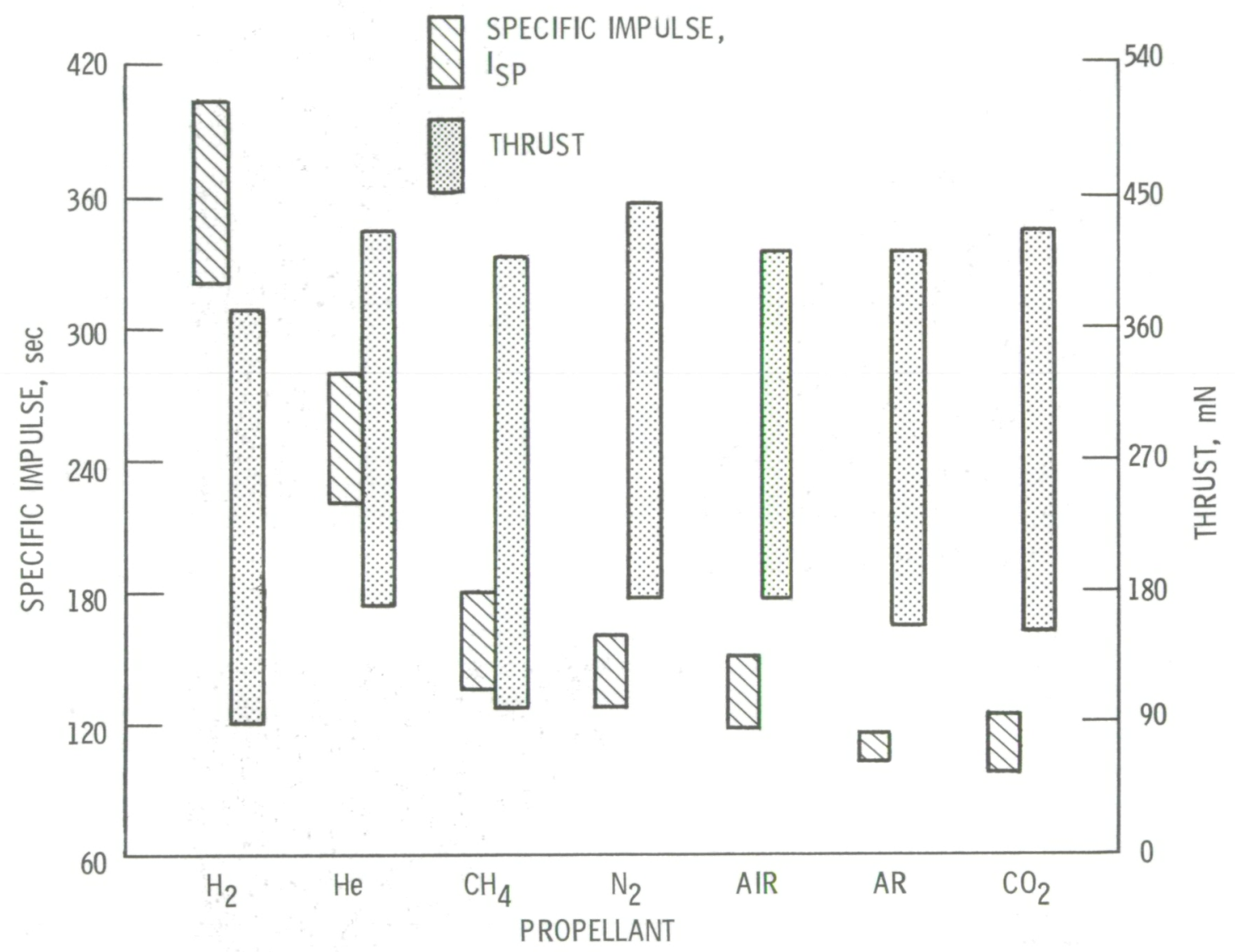

Figure 8. - Specific impulse and thrust ranges for a multipropellant resistojet operated on various propellants at a heater temperature of $1400^{\circ} \mathrm{C}$. 


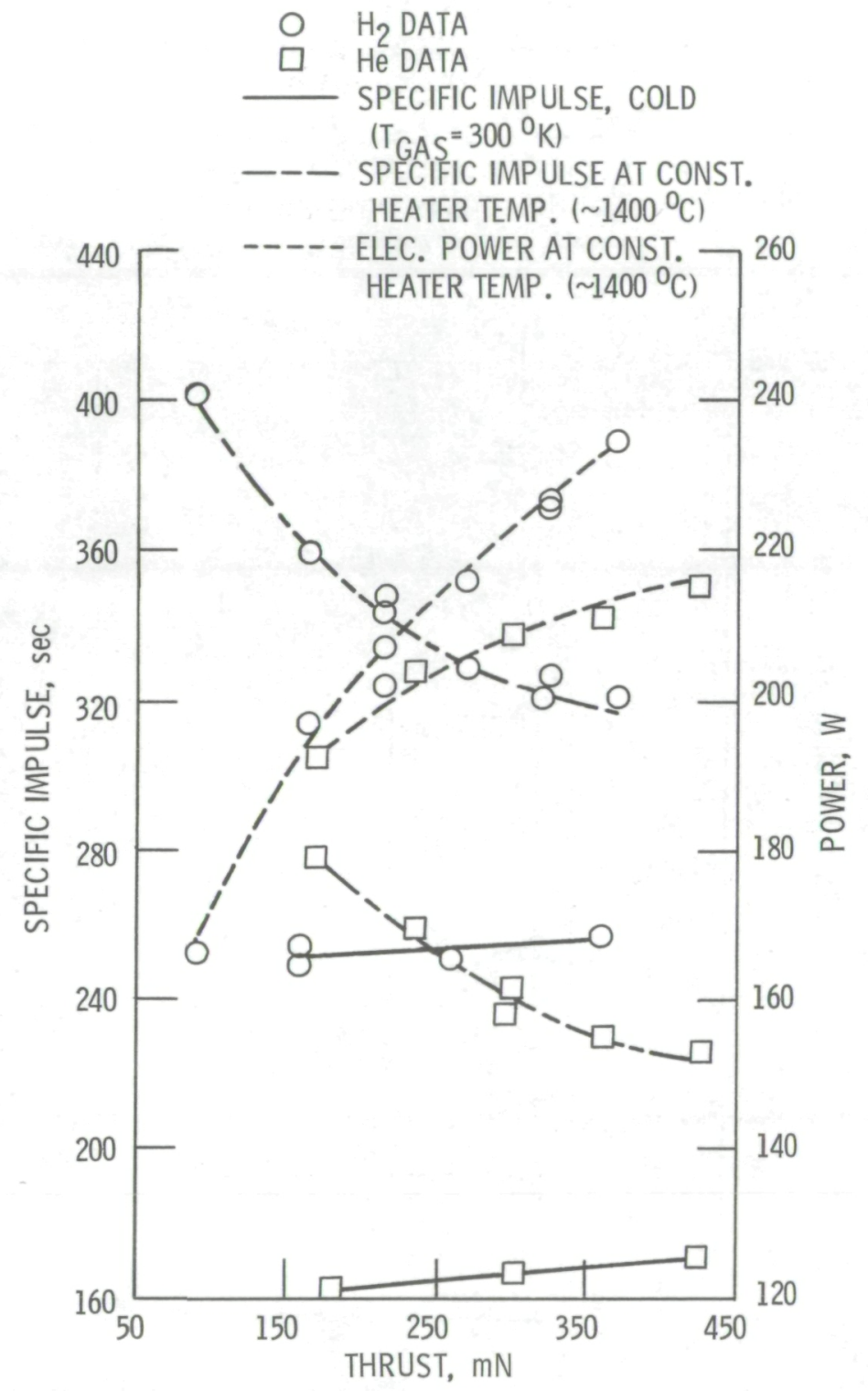

Figure 9. - Specific impulse and input power vs. thrust for multipropellant resistojet using $\mathrm{H}_{2}$ and $\mathrm{He}$. 


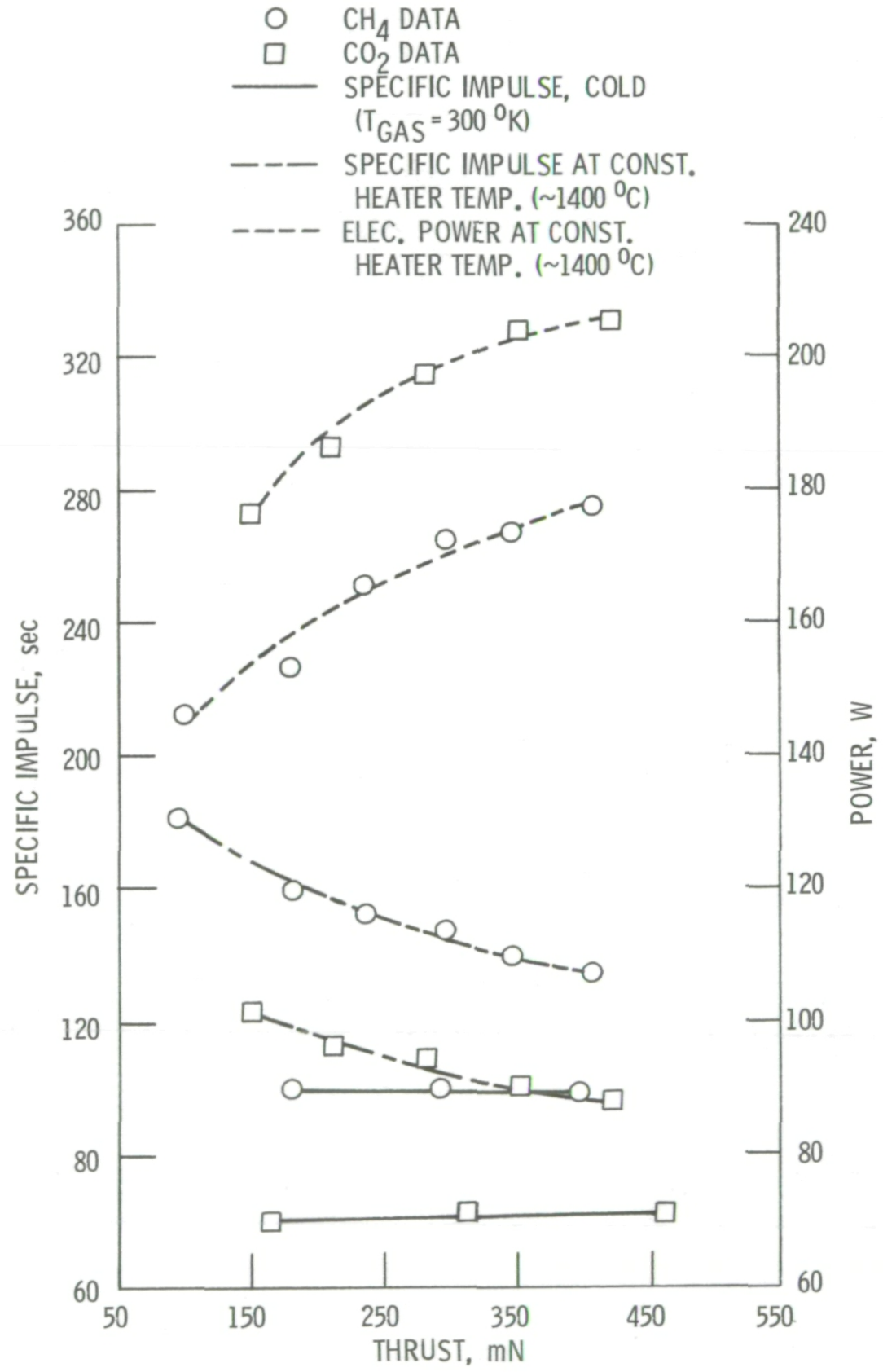

Figure 10. - Specific impulse and input power vs. thrust for multipropellant resistojet using $\mathrm{CH}_{4}$ and $\mathrm{CO}_{2}$. 


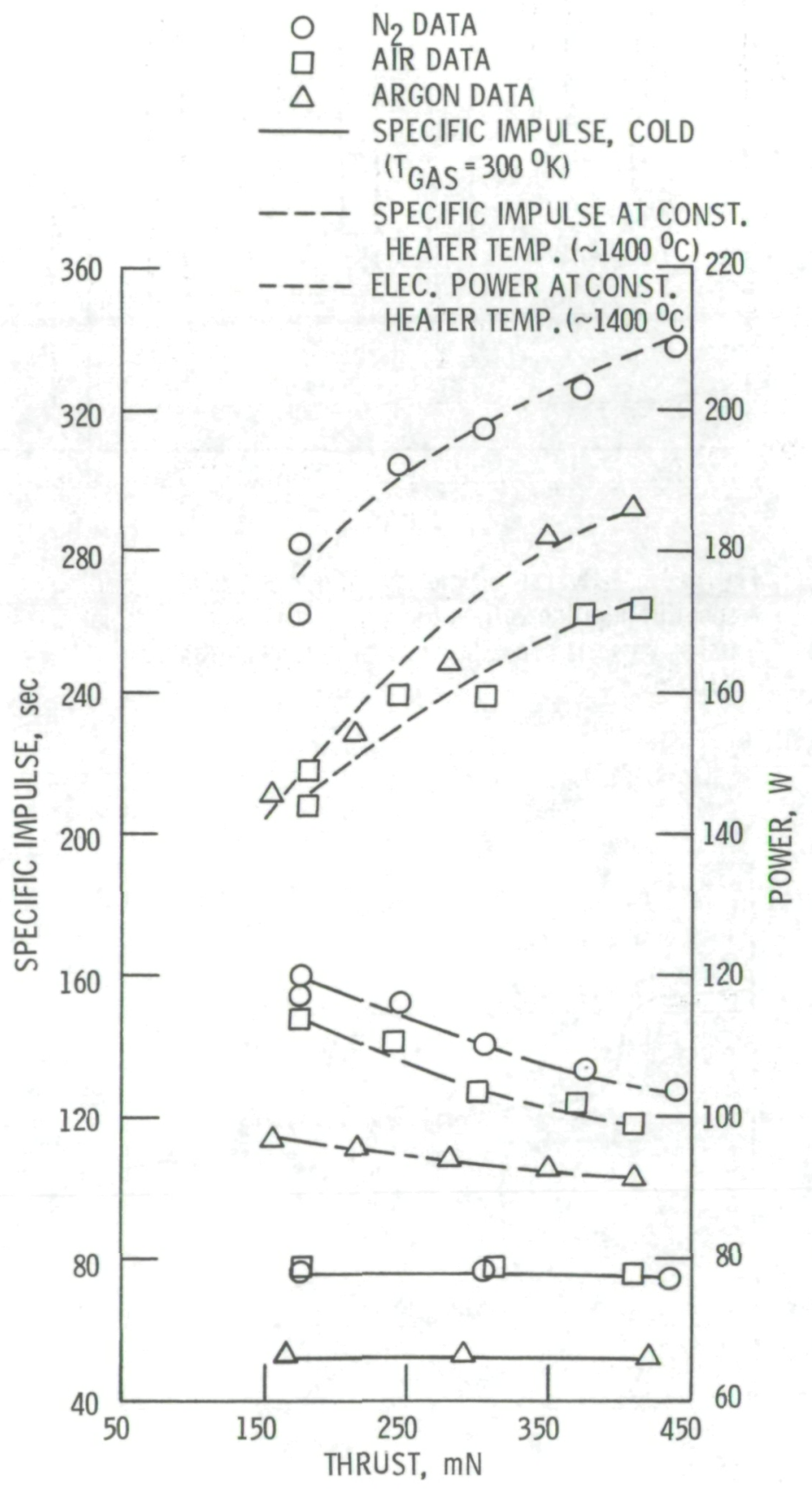

Figure 11. - Specific impulse and input power vs. thrust for multipropellant resistojet using $\mathrm{N}_{2}$, air, and Ar. 


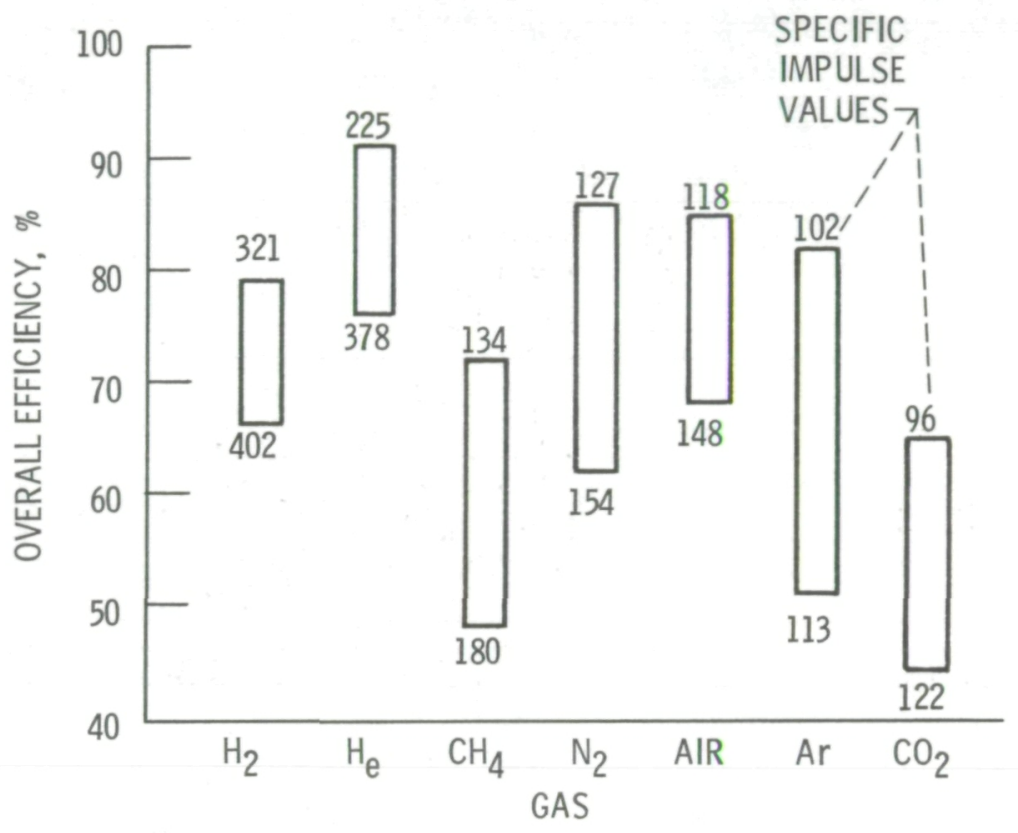

Figure 12. - Overall efficiency ranges and corresponding specific impulse values for multipropellant resistojet using various propellants at heater temperatures of $1400^{\circ} \mathrm{C}$.

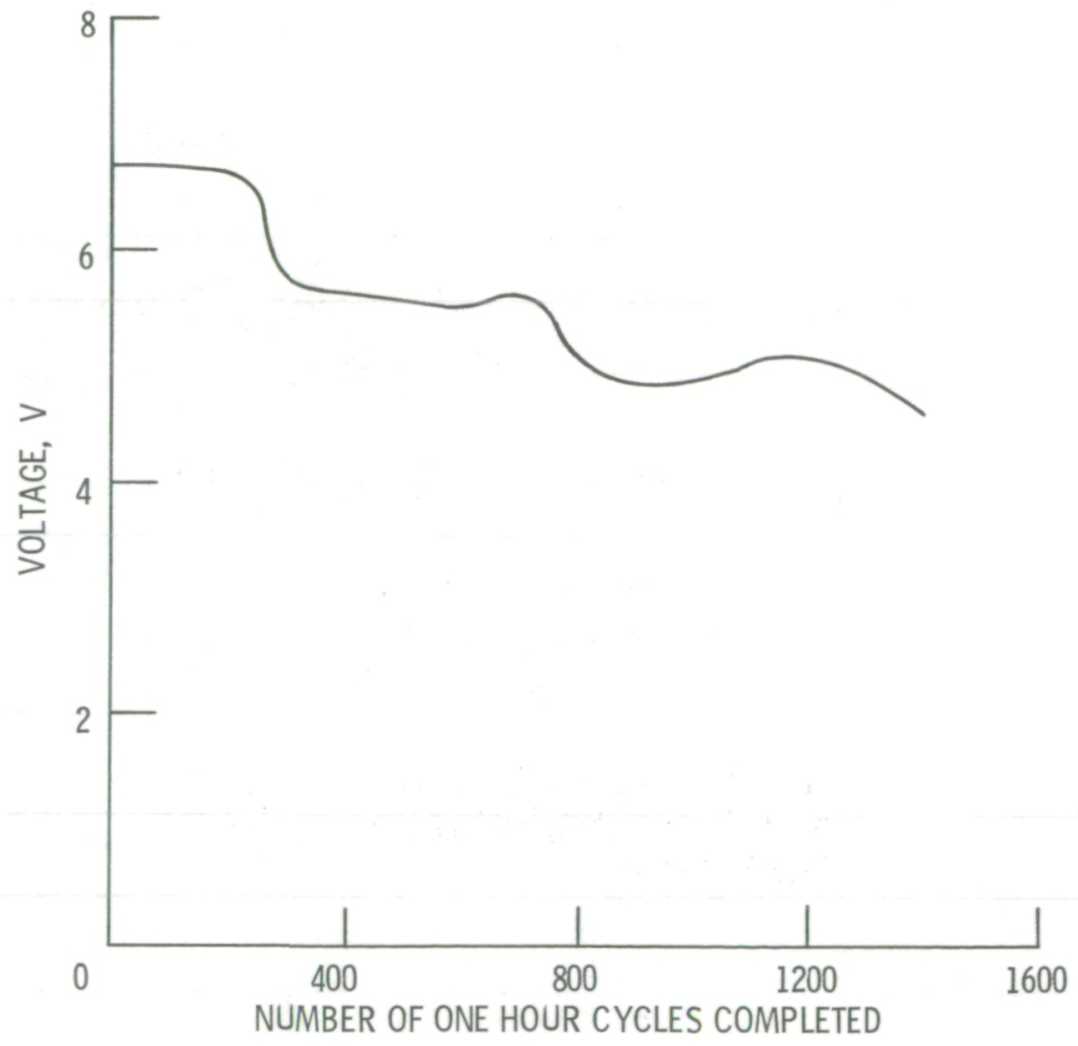

Figure 13. - Life test thruster heater voltage vs. time. $83 \%$ Heater duty cycle. $29 \mathrm{~A}$ heater current. 


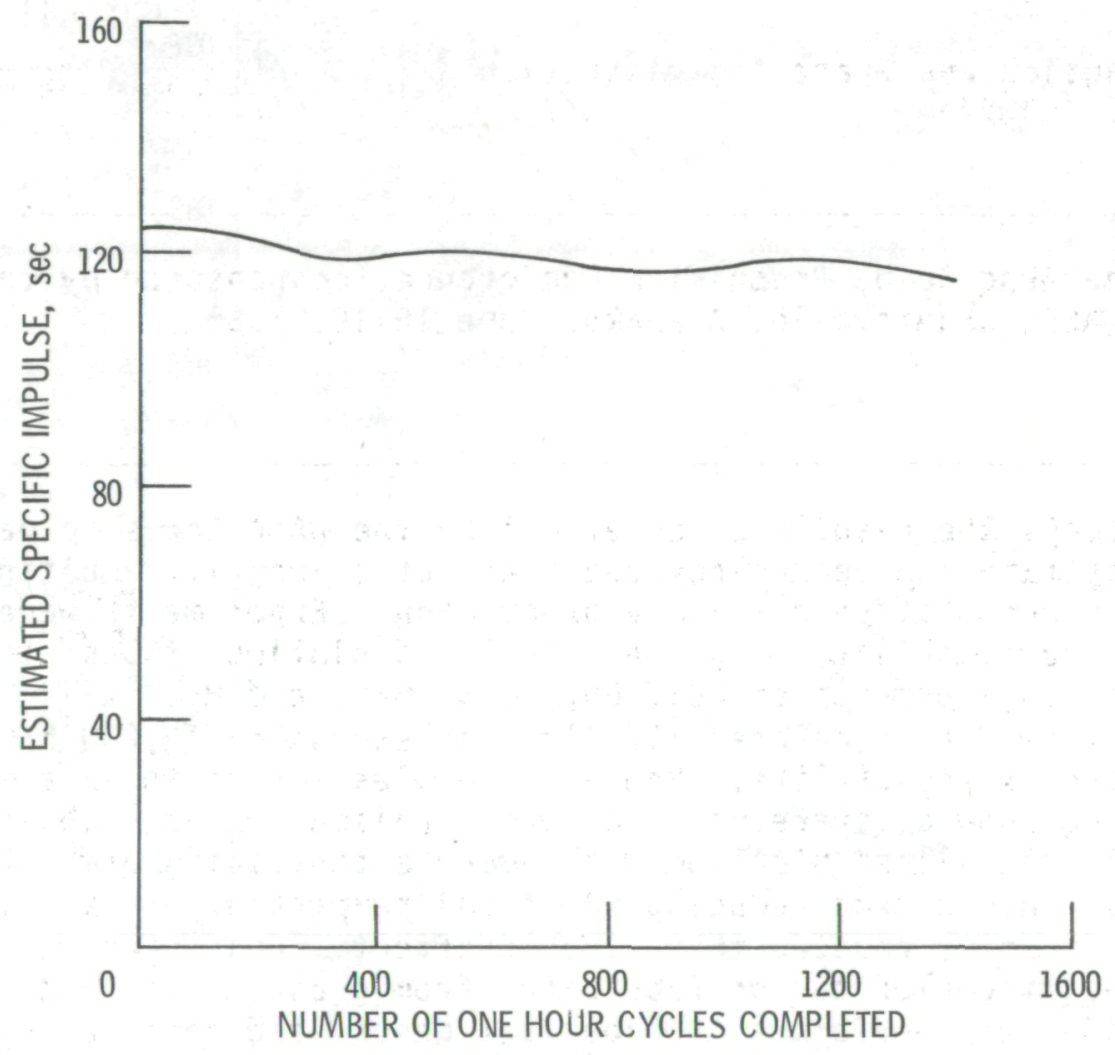

Figure 14. - Estimated specific impulse for life test multipropellant resistojet vs. time. $83 \%$ Heater duty cycle. 


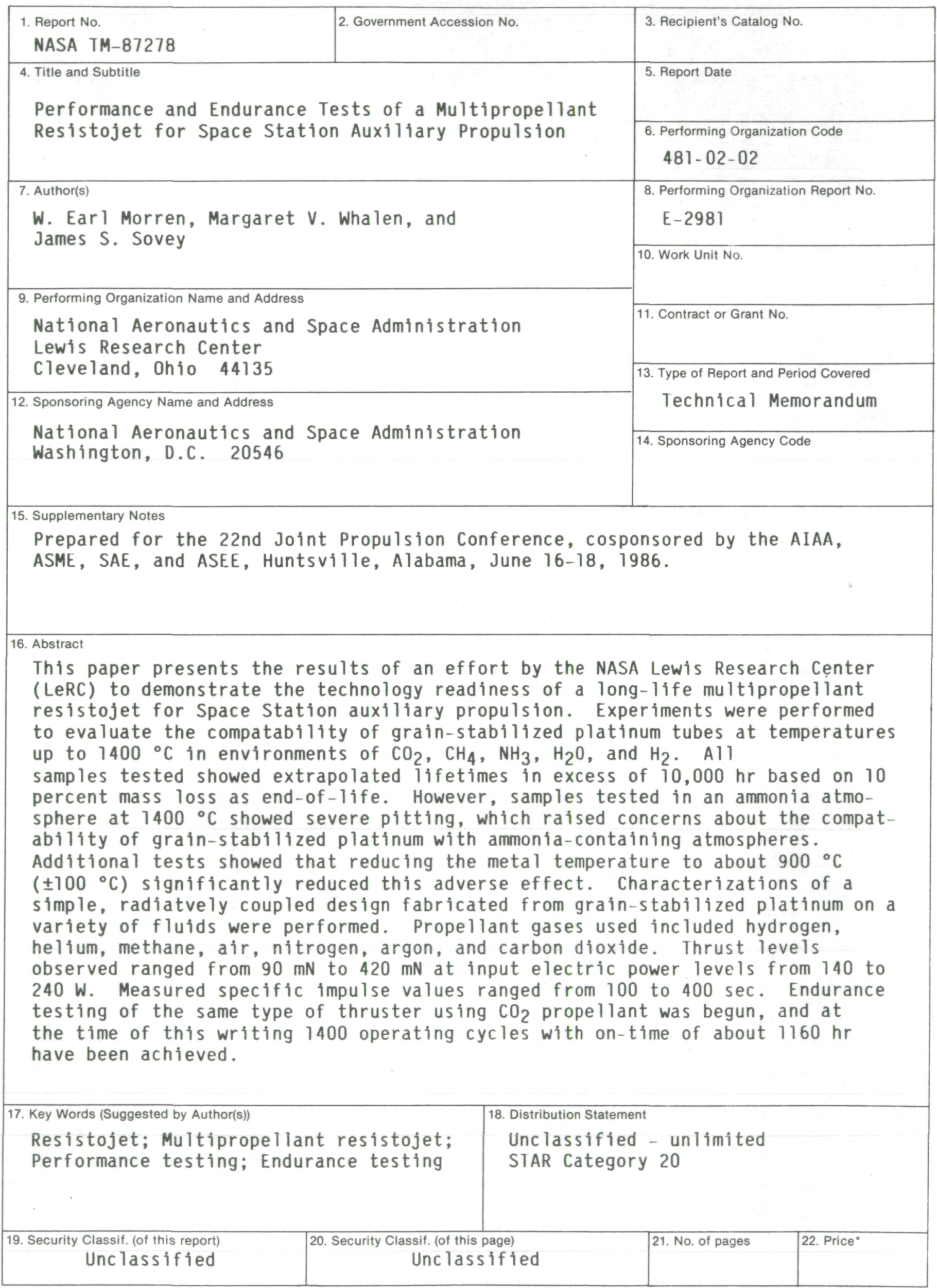

${ }^{\star}$ For sale by the National Technical Information Service, Springfield, Virginia 22161 


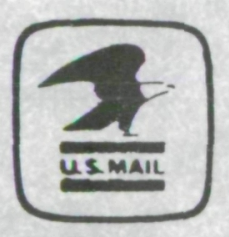

Official Business

Penalty for Private Use $\$ 300$
Postage and Fees Paid National Aeronautics and Space Administration NASA-451 